\title{
The privatised self? A theological critique of the commodification of human identity in modern technological age in an African context professing Ubuntu
}

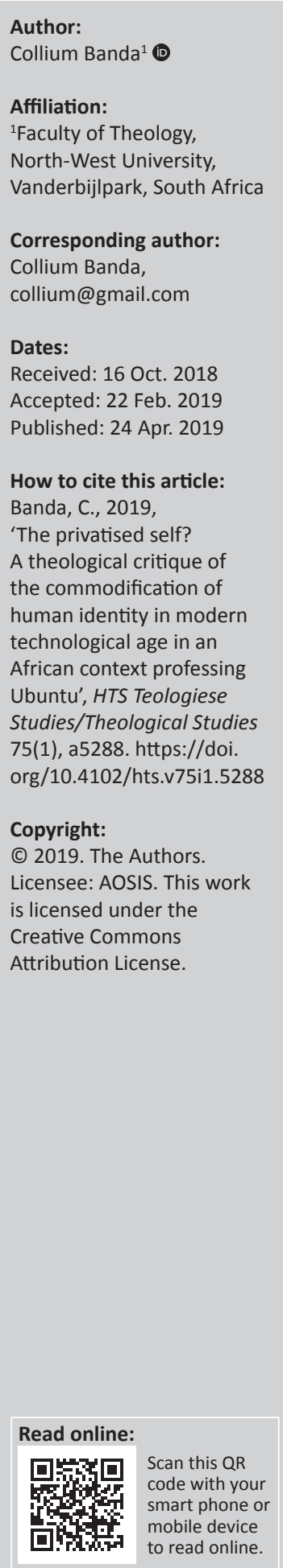

Modern technology has significantly improved human life. However, its serious negative element in Africa is fostering human self-sufficiency and independence that ultimately subvert human solidarity and interdependence that are highly valued by ubuntu philosophy. The main question of this article is: From the perspective of the African communal tenet of $u b u n t u$ that places human identity within communal solidarity and interdependence, how can we theologically respond to the commodification of human identity in the modern technological age? Consequently, a description is made of how modern technological age promotes human self-sufficiency that leads to the commodification of human identity. Further, the link between the commodification of human identity and privatisation of self is described. The challenge of ubuntu philosophy expressed by the Nguni proverb umuntu ngumuntu ngabantu is unpacked, and its challenge to the human self-sufficiency promoted by the technological age is explored. The image of God is proposed as an important theological tool of responding to the commodification of human identity. Finally, some steps that the churches can use to mitigate the commodification of human identity are presented. Technology is here to stay; rather than resist it, Christians must embrace it from a perspective informed by the image of God.

Keywords: Human identity; Ubuntu; Commodification of human identity; Image of God; Privatisation of self.

\section{Introduction}

The article theologically critiques the effects of modern technology on human identity from the African perspective of ubuntu philosophy. ${ }^{1}$ In its basic form, ubuntu is a summary of the Nguni proverb umuntu ngumuntu ngabantu that loosely says, a person is a person through other people. Without a doubt, modern technology has radically transformed and improved human life in many ways that cannot be compared with any past human history. However, despite its many unparalleled achievements, a serious negative element of modern technology in Africa is fostering human selfsufficiency and independence that ultimately subvert human solidarity and interdependence that are highly valued in ubuntu philosophy. The main question that this article seeks to answer is: From the perspective of the African communal tenet of ubuntu that places human identity within communal solidarity and interdependence, how can we theologically respond to the commodification of human identity in the modern technological age? This main question is answered by first describing how modern technological age promotes human self-sufficiency that leads to the commodification of human identity. The article further describes the link between the commodification of human identity and how people end up privatising themselves. However, in Southern Africa there is a considerable appeal to ubuntu as a guiding principle in human living. Therefore, ubuntu philosophy as proclaimed by the Nguni saying, umuntu ngumuntu ngabantu, is explored to critique the human self-sufficiency promoted by the technological age. The article proposes the image of God as an important theological tool of responding to the commodification of human identity in an ubuntu professing technological world. Finally, some steps that the churches can use to mitigate against the commodification of human identity are presented. As pointed out by Magezi (2015:1), 'The penetration of technology into every sphere of people's lives suggests that technology has to be embraced'. Consequently, the article will argue that technology is here to stay; rather than resist it, Christians must indeed embrace it from a perspective informed and shaped by the communal image of God.

1.African variations of ubuntu include botho (Sesotho), unhu (ChiShona), utu (Kwiswahili) and umundu (Kikuyu). 
However, from the onset, it must be pointed out that this article is neither anti-technology, nor does it seek to portray modern technological advancement as an evil to be avoided at all costs. Rather, the article addresses modern technology's negative effects on human identity with the firm conviction and acknowledgment that unprecedented developments have made the world better by immensely improving the quality of human life. Furthermore, the article notes that in modern Africa, the concern that modern technology has led to the commodification of human identity is ironically conflicted by the reality of extreme economic poverty caused by serious lack of scientific and technological developments in fields such as medicine, energy, mining and agriculture. On the one hand, it can be affirmed that in sub-Saharan Africa there is an increase in poverty because of lack of technology. Yet, the havoc on human identity caused by current developments needs to be theologically evaluated and corrected so that future technological advancements may occur in ways that do not have an adverse effect on human identity.

\section{Modern technological age and commodified human identity}

It is argued that the modern technological age has given rise to the commodification of human identity. This section describes how the modern technological age has commodified human identity.

\section{Commodification of human identity in the modern technological age}

While technology has enabled modern people to be independent and highly efficient, it has resulted in the commodification of human identity by promoting the idea that human identity is determined by the technological commodities used by people. The Merriam-Webster Dictionary (2018) defines commodification as treating something that cannot be owned or that belongs to everyone as 'a product that can be bought and sold'. Commodification turns something universally accessible into something only accessible to the few who can pay the price. As an example, the commodification of water converts it from a human right that must be enjoyed by all people into a private thing that can only be enjoyed by those with the money to pay for it. Similarly, the Cambridge Dictionary (2018) defines commodification as 'the fact that something is treated or considered as a commodity'. With reference to human identity, commodification of human identity means that a person's value ceases to be based on the intrinsic fact of being human and is based on extrinsic qualities that can be acquired by an individual. One can call this the 'thingification' of human identity because it is reduced to a thing that can be traded. Identity becomes a commodity that can be bought and sold. With specific reference to the commodification of the bodies of human beings, Jones (2016) says:

There are endless ways bodies can be turned into commodities. Marketers offer thongs and push-up bras, even to children, suggesting that the point of bodies is to create market demand for undergarments, that image-bearers need to be dressed up and sexualised in order to have worth ... The advertising industry uses sex to sell almost everything (cars, beer, clothes, technology), making the implicit claim that bodies are for sale or require upgrading via market goods in order to demand a good price ... Purveyors of self-help advice encourage people to use their bodies as currency in relationships, to withhold or offer sex to get what they want. (pp. 229-230)

The text shows the various ways of 'thingifying' human identity. While some people are physically trafficked and sold into slavery, some people, including those who are supposedly liberated and empowered, have their bodies and images marketed as objects of pleasure or commodities to be possessed. The essence of human identity becomes anchored on commodities owned by the individual or on marketable functions fulfilled by the individual.

In this perspective, the African popular saying that a person is person through other people - umuntu ngumuntu ngabantuis rapidly replaced by the saying that a person is a person through becoming a possession owned by the technological gadgets and brands - umuntu ngumuntu ngezinto. Increasingly, a gadget for communication becomes a gadget for identity. Thus, one's human identity begins to be shaped by a commodity. This commodity-related human identity may be a huge contributing factor in the high sales of some technologies. This also shows that modern people have become mechanised beings whose identity is shaped by the machines they use. A commodified object loses its own independence, identity, purpose and essence, and takes on new characteristics conferred to it by its new possessor (Hadebe 2017:2). Therefore, in the modern technological age, the value of human identity is placed on the extrinsic qualities and not on the intrinsic value.

With reference to the modern technological age, the commodification of human identity can be viewed from two angles, namely the treating of people by technological companies as commodities to be traded and the basing of ideal human identity on the possession of technological goods. In a paper entitled, Commodification and transfiguration: Socially mediated identity in technology and theology (2018), Ron Cole-Turner highlighted that technological companies treat people as commodities to be traded because their revenue is generated by providing platforms for people to share their personal data. While social media companies such as Facebook have categorically ruled out selling people's data to outside buyers (Wagner 2018), they exist by promoting people to share their personal data publically; ultimately, social media companies actually trade people's personal data. With reference to Facebook, Wagner (2018:n.p.) categorically states: 'Facebook collects a lot of data about you - everything from your email address to the strength of your phone's battery ... [and] ... uses that data to make money'. This means that social media companies relate to people's personal data as commodities to be marketed.

The form of commodification that is of main interest to this article is one where ideal human identity is based on the possession and use of technological goods. The modern technological age fosters the idea that human identity is derived from the use or possession of technological gadgets. 
However, not only is there a drive to possess the latest smart technological gadgets, there is also a concerted drive to depend on the technological commodities in ways that ultimately replace people. Although promoting efficiency, reliance on people is undermined, resulting in mechanised humanity and materialistic communities.

\section{Commodification of human identity and human self-sufficiency}

An attribute of commodifying human identity in the modern technological age is human self-sufficiency. The technological age increasingly creates self-sufficient human beings who attempt to be in full control of their lives in ways that either diminish reliance on other people or even eliminate it entirely. For example, Sellen et al. (2009:62) point out: 'Computerenabled creativity means we can all become our own producers, programmers, and publishers, whether in our personal or professional lives, with potentially far-reaching consequences'. The statement appreciates the extent to which computer technology has transformed modern life, resulting in 'the growth of creative power' (Sellen et al. 2009:62). Before the advent of smart technology, people entirely relied on experts for things such as personal photographs, typing of documents and printing of documents. However, for many modern people, except in cases where a highly professionalised touch is needed, many people do self-production, and some self-produced items are just as good as the professionally produced ones. The testimony is the many selfies and selfproduced video abounding social media.

The need for other people has also been diminished or totally eradicated in some cases. As Sellen et al. (2009) point out:

It is not simply that we are increasingly using computers in routine but selected activities, such as to write reports or do our tax returns. Computing now underpins almost every aspect of our lives, from shopping to travel, from work to medicine. (p. 61)

Smart technologies such as Google Maps and GPS have diminished the need to rely on strangers for directions to one's destination. Even in cases of illness, the internet now functions as the first port of call for many people. Problems that needed technical experts to solve can now be solved just by googling for solutions on the internet. This development creates self-reliant and self-contained human beings and diminishes the value of interpersonal relationships. The end result is the dehumanisation of humanity by creating a humanness that only thrives on non-human things. Even self-testing medical kits undermine the need for face-to-face consultation and even counselling by human medical experts. The development of self-driving cars and self-regulating machines diminish both the need and value of human labour. In areas of work and production, technologies have removed the need for large team of workers, and in some areas, human labour has been totally eradicated. What required the efforts of many people in the former generations, now requires just the bare effort of one person.

While this section has analysed the extreme influences of technological advances on humanity, the article has already acknowledged that in Africa there is also another extreme end of increase in poverty and other aspects of human suffering because of a lack of technology. It, however, belongs to a different study to clearly nuance the relationship between increase in poverty and lack of technological developments.

\section{Modern technology and the quest for transhumanism}

Modern technology promotes the idea of superhumans who can accomplish much of what they desire. Peters (2010:215) highlights that modern technology has given humans the power of 'self-alteration', which affirms that being human in modern times is far different from what it meant just a few years ago where it meant being managed by various human limitations. Peters (2010:215) further adds: 'Through the advance of technology, we are ready to transform the make-up of the human being and perhaps even create a post human reality'.

Therefore, as Illing (2018) observes, modern technological advancements are not 'just changing society, they are changing what it means to be human'. In concert, Brulin (2013:5) says: 'Being human in this technological age is challenging'. To a large extent, modern life has become so dominated by technology that we do not know how to live without it. DeGrazia (2005) and Bess (2010) argue that modern technologies have enhanced human sufficiency by liberating modern people from many situations that were beyond the control of people in past generations. In past generations, being human meant accepting one's limitations and being governed by them. Illing (2018) highlights science historian Michael Bess stating that:

...what we're on the verge of doing with bioengineering technologies like CRISPR ${ }^{2}$ is going to be so qualitatively different and more powerful that I think it's going to force us to reassess who we are and what it means to be human. (n.p.)

One could say that before these technological discoveries were made, being human meant subjection to the many limitations in which people found themselves. He adds: 'Bioelectric implants, genetic modification packages, the ability to tamper with our very biology - this stuff goes far beyond previous advances' (Bess, in Illing 2018). Bess is highlighting that modern technology means that people are no longer subject to human limitations that affected older generations. It is not long ago that people unable to have children had very limited options available for them to address this inability. Besides high costs, modern technology has given people the power to transcend many human limitations that meant a death sentence a few years ago. Technological developments free human beings from dependency on supernatural forces by empowering them to realise their human sufficiency and to depend on it.

\section{Commodification of human identity and the undermining of human solidarity}

A significant challenge with modern technology is the creation of human identity that undermines human solidarity and 2.clustered Regularly Interspaced Short Palindromic Repeat. 
interpersonal human connections. Sellen et al. (2009:61) highlight that the modern technological age is characterised by 'growth of techno-dependency' and 'growth in hyperconnectivity'. These characteristics mean that modern people's lives are controlled by technology in an enslaving effect. As they further add:

Despite the ability of such new tools to improve efficiency and save us time, such 'digital presence' increasingly consumes our time rather than save it. Communication devices are now filling our lives up instead of releasing us from burden. (Sellen et al. 2009:61)

What emerges from the commodification of human identity in the modern technological age is the fostering of human identity that undermines human solidarity. As already noted from the above sections, in some cases there is replacement of the need for human solidarity. We earlier noted Illing's (2018) concern that people in the technological age are losing their ability to be in the world in a way that is not mediated by some electronic appendage. In concert, Bess (in Illing 2018) raises concern about how 'everybody seems to be walking around campus mindlessly staring at their phones'. Likewise, Brulin (2013:1) asks an important question: 'What is actually happening to humans when their daily activities are being replaced and controlled by technology?' Sellen et al. (2009:61) observe that in the technological age, 'growth in hyperconnectivity carries with it both the benefits and the pressures of being connected "anywhere, anytime". This hyperconnectivity has turned modern people into mechanised beings who can barely survive without their technological gadgets. While it is possible that we may have since acquired the needed multi-tasking skills, a large portion of our humanness is suppressed by this overreliance on technology.

While these technological gadgets indeed make life easier and safer when one considers that relying on GPS may be safer than going around asking people for directions, the technological gadgets 'are rapidly pushing us away from the world' (Illing 2018:n.p.). The fact that we find it difficult to sit at dinner tables with close family members without glancing at our smartphones, and that we constantly have to be pleaded with to switch off our phones in meetings and even find it burdensome and offensive to be asked to do so, indicates the extent to which we have migrated from real human communities to technological space. One may say modern human life is filled more with online connections than real life.

However, this argument is countered by the bare fact that technology through hyperconnectivity has actually enhanced wider human connectedness, because we are connected to a wider circle of people than just our neighbours and family. The serious problem is that often online interpersonal touch seems to hinder our ability to enjoy real interpersonal presence as exemplified by the many absent-minded bodies at dinner tables while actively present-minded in online communities. Further, while online interpersonal touch has replaced real interpersonal touch, online relations are superfluous because they do not engage all the person's five senses. From her study of the impact of smart technology, Brulin (2013:17) reports a respondent who pointed out that the possibility to always reach her friends online decreased her need to meet them face to face. Another respondent reported that she no longer frequently met people anymore because she increased her usage of platforms such as instant message, chat and Skype (Brulin 2013:17). This shows the extent to which the commodification of human identity by technology undermines human solidarity and interdependence.

\section{Commodification and the resultant privatisation of the self}

Ironically, technology's commodification of human identity promotes people to privatise their inner selves from the public. It is true, as Sellen et al. (2009:61-62) point out, that 'hyperconnectivity also has the power to mobilise us, as citizens and members of global communities; we are now in touch in more ways, and with more people, than ever'. Indeed, social media connects us with the entire world in an instant and mobilises people from across the world towards specific actions. Therefore, it can be argued that increased hyperconnectivity enables people to actually open themselves up to the whole world. In fact, Sellen et al. (2009:62) add that modern people are 'developing an ever-increasing "digital footprint"'.3

However, while many people do indeed post personal data on social media, it can be questioned if what is posted on the internet does not advertently shift the focus of the public from the person's deeper issues to surface issues. In other words, to what extent does posting one's personal data on the social media not intended to parry away people's attention from personal inner selves? A person who is undergoing a stressful moment may post a positive image that hides the pain one may be going through. There are many sad situations when the world has woken up to the shock of learning that the woman who has been posting beautiful pictures of herself and her partner is actually in an abuse relationship. Therefore, the problem of technology, particularly social media, is the privatisation of self by using the public domain to hide one's private life or as a way of disengaging with one's inner being. By privatisation it is meant that much of the high interconnectivity is happening on the outside and not on the inside. One could say, we are well connected online but so disconnected in real life. We know each other well online, but are total strangers or unconnected in the real world.

Essentially, human identity in the technological age thrives on external appearances. We generally use social media to portray a positive image of ourselves, even though we may fail to do so or even achieve the opposite of the good we seek to achieve. The challenge is that a focus on our external

3.Sellen et al. (2009:62) explain that sometimes 'digital footprinting' occurs in ways we do not desire and also in ways we do not know about such as giving up personal we do not desire and also in ways we do not know about such as giving up personal
data into the databases of government agencies and other public, as well as private, institutions. 
appearance may keep the focus away from what may really be happening to us. In addition, there is a significant portion of ourselves that is only available on social media and is often suppressed at real interpersonal levels (Taylor 2011).

Mass migration to the virtual world promotes dependence on electronic bandwidth instead of interpersonal links in human relationships (Brulin 2013:17). The problem is that the freedom provided by technology to freely express ourselves may inhibit us from developing the skills needed to engage at interpersonal level, resulting in the privatisation of self by limiting human accessibility and human connection to people with appropriate technological gadgets (Brulin 2013:17). Rather than the communal self, who socialises and interacts with people at an interpersonal level, technology tends to privatise people by making them accessible only at online level and by those with the appropriate technological gadgets.

However, the charge of privatisation of self is challenged by the numerous digital footprints deliberately created by individuals. How can one say people in the modern technological world have privatised themselves when many give a blow-by-blow account of their daily activities on social media? The problem and weaknesses in the modern technological age are highlighted by Taylor (2011) who points out:

[S]ocial media has caused us to shift away from expressing our self-identities and toward constructing facades based on the answers to these questions, 'How will others look at me?' and 'How can I ensure that others view me positively?' The goal for many now in their use of social media becomes how they can curry acceptance, popularity, status, and, by extension, selfesteem through their profiles and postings. (n.p.)

In the digital space, some people do and say things they would never do and say in real life. Some people are more open about themselves on the net than in real life. Often, this privatisation of the human identity thrives on fake appearances and false connections.

\section{The challenge of ubuntu to the modern technological age in Africa}

In the African context, the underlying background in which the self-sufficient human being of the modern technological age is created is the communal philosophy of ubuntu. This leads to the question, how do ubuntu and modern technology challenge each other in Africa?

\section{Ubuntu as the basis of human identity in traditional Africa}

Human identity in traditional African thought is informed and shaped by the Nguni proverb umuntu ngumuntu ngabantu, which is summarised by the concept of 'ubuntu'. In the SeSotho languages, the concept is expressed as motho ke motho ka batho. There is an inexhaustible body of literature on ubuntu and it is beyond the scope of this article to dwell on the various views on ubuntu (Gade 2011; Gichure 2015;
Metz 2011; Shutte 2001). While the saying umuntu ngumuntu ngabantu functions as a foundational tenet to many southern African traditional cultures, it is difficult to translate and unpack concisely in English. Often, one has to carefully consider the context in which it is expressed. Interpretations range from the loose etymological translation, 'a person is a person through or by other people' or 'a person is a person because of other people', to John S. Mbiti's (1990:106) philosophical rendering, 'I am, because we are; and since we are, therefore I am'. To emphasise ubuntu as the basis of human identity in Africa, John Mbiti (1990) states:

In traditional life, the individual does not and cannot exist alone except corporately. He owes his existence to other people, including those of past generations and his contemporaries. He is simple part of the whole. The community must therefore make, create or produce the individual; for the individual depends on the corporate group. (p. 106)

That is, in traditional African thought people are expected to be corporate and social beings. As explained by Manyonganise (2015:1): 'In ubuntu, corporate existence is a virtue and the human being is the centre of all relationships'. Letseka (2012:48) highlights that ubuntu articulates social interdependence and a deep rootedness in community. Mbiti's rendering of ubuntu as 'I am, because we are; and since we are, therefore I am' is embedded on the notion of social independence (Letseka 2012:48). Therefore, the essence of human identity is belonging and being belonged to, which can be summarised as communality.

Essentially, ubuntu is a moral term denoting 'humaneness, personhood and morality' (Letseka 2012:48). Upon explaining that the various African communities describe ubuntu differently, Gathogo (2008:45) adds that ubuntu is ' $[b]$ asically ... both a philosophical and a religious concept that defines the individual in terms of his or her relationships with others'. In this case, to be human means to belong to other people, and in traditional Africa, true worship enhances the unity of the community (Mbiti 1990:2-3; Nyathi 2001:9).

Ubuntu is essentially 'a moral theory' (Letseka 2012:54). Manyonganise (2015:1) amplifies Chimuka rendering the Shona equivalent to ubuntu, hunhu, as the ontological, epistemological and moral fountain of African philosophy. As a moral theory, ubuntu engenders compassion, justice, reciprocity, dignity and the building, maintaining and strengthening of communal life (Bessler, in Letseka 2012:54). The saying umuntu ngumuntu ngabantu affirms the identitygiving power of the community. This means that one must seek to transcend from being umuntu and be abantu, which calls for the inclusive virtue of hospitality to one another.

\section{Problem in using ubuntu to analyse human identity in modern African technological age}

Can ubuntu be a useful concept of analysing human identity in the modern African technological age? Despite its ubiquitous use as an ideal to be pursued by all Africans, ubuntu is a highly contested philosophy in contemporary Africa. Therefore, before spelling out its positive elements, it is important to 
highlight some shortcomings within the concept. These shortcomings need to be addressed when using ubuntu to critique and evaluate human identity in the technological age.

Firstly, a challenge of using ubuntu to critique the modern technological age is that it tends to be a concept embedded in the imagined glorious past 'world that is valuable to historians and archaeologists' (Speckman 2007:xviii). Ubuntu tends to idolise and idealise the undeveloped stage of ancient African societies when life was simple and mostly agrarian. On the other hand, modern societies are complex and highly technological and, therefore, different.

Secondly, feminist and womanist scholars have decried the overly masculine nature of ubuntu, which makes it oppressive and exclusive (Chisale 2018:1, 4; Manyonganise 2015:2). Manyonganise (2015:3) declares 'ubuntu is exclusive' and cites several instances where the notion of ubuntu is used to segregate and oppress women, adding, ' $[s]$ trict adherence to the concept creates exclusionary identities which are often viewed as "others" within specific boundaries' (Manyonganise 2015:3).This statement highlights not just the gender bias in ubuntu but also its tribal limitedness (Magezi 2017:114). Not only is it embedded in patriarchy, it is also embedded in tribalism where often the definition of authentic human being does not transcend beyond one's tribe (Magezi 2017:114). Directly related to this, ubuntu idealises an imagined past that is often used by the powerful community elders to reign over younger people. Instead of pointing to the future, it points to the past.

Thirdly, Gathogo (2008:46-50) highlights the African contradiction of subscribing to ubuntu and yet so rife with occurrence of ubulwane, animal-like behaviour of violence, nepotism, corruption, the oppression of women and children, the suppression of weak tribes by the powerful tribes, oppressive and ruthless chiefs. Therefore, it is highly contestable if, in traditional African societies, all the people, especially women and children, ever experienced the full benefit of ubuntu. Despite its many weakness, ubuntu significantly spells out the ideal human identity that all people should strive for. Chisale (2018:4) says ubuntu has weaknesses just like other philosophies and worldviews, but 'it nevertheless guides communities on how moral life is and ought to be'. Therefore, its positive elements remain useful for analysing human identity in the technological age.

\section{Ubuntu human solidarity}

Umuntu ngumuntu ngabantu is essentially a proverb of human solidarity that affirms belonging together. It warns those who want to be lone-rangers against aloofness. The significance of human solidarity is affirmed by Desmond Tutu as follows:

In our African language we say, 'a person is a person through other persons'. I would not know how to be a human being at all except (that) I learned this from other human beings. We are made for a delicate network of relationships, of interdependence. We are meant to complement each other. All kinds of things go horribly wrong when we break that fundamental Law of our being. Not even the most powerful nation can be completely selfsufficient. (in Gathogo 2008:44)

Tutu highlights that human solidarity is foundational to the philosophy of ubuntu. Solidarity and interdependence are important elements in traditional African cultures as affirmed by other proverbs. For instance, the Ndebele of Zimbabwe warn that people do not bury themselves (Umuntu kazingcwabi). They also warn that no single log can make itself to glow (Ukhuni aluzikhwezeli). The Ndebele affirm interdependence by drawing attention to the fact that hands wash each other (izandla ziyagezana). ${ }^{4}$ These proverbs and many others like them affirm that human beings are only able to live as true human in solidarity with other humans. Saying that people do not bury themselves does not just point to the fact that people are buried by other people, but cautions those who stay away from other people's funerals, that when they die they too will need other people to bury them. Such sayings also serve as subtle warnings to those who trust their wealth and think that because they are rich they have no need for other people. The essence of the proverb is captured in the common practice of joining burial societies. Even wealthy people are expected to join burial societies because 'your money will not bury you' (Imali yakho ayikugcwabi). No matter how glamorous a funeral may be, but it's shunned by many people, it is no longer a funeral but a discarding of a dead body. A person is a person through other people.

According to Emeritus Archbishop Desmond Tutu (1999), ubuntu means:

... my humanity is caught up, is inextricably bound up, in theirs. People belong to one another. We say a person is a person through other people. It is not 'I think therefore I am'. It is rather, 'I am human because I belong'. I participate, I share. A person with ubuntu is open and available to others, affirming of others, does not feel threatened that others are better. For he or she has a proper assurance that he or she belongs to a greater whole and is diminished when others are humiliated or treated as if they were less than human. (pp. 34-35)

According to Tutu, in traditional African thought, human identity is communally derived, shaped, nurtured and focussed. Thus, we are not independent individuals living by themselves and only for themselves isolated from the community. Rather, we are to be in communal relationship with the community.

About the essence or the nature of this communal human identity, Mbiti (1990) says:

It is a deeply religious transaction. Only in terms of other people does the individual become conscious of his own being, his own duties, his privileges and responsibilities towards himself and towards other people. When he suffers, he does not

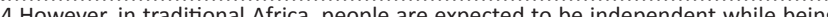
intercle endent on others. Sayings such as 'you give a person a hand and he wants the the whole arm - umnika isandla usefuna ingaloyonke - describe those who parasitically want to abuse the generosity of other people. It is good to ask for a hand, but to demand the whole arm is bad. 
suffer alone but with the corporate group; when he rejoices, he rejoices not alone but with his kinsmen, his neighbours and his relatives whether dead or living. When he gets married, he is not alone, neither does the wife 'belong' to him alone. So also the children belong to the corporate body of kinsmen, even if they bear only their father's or mother's name. Whatever happens to the individual happens to the whole group, and whatever happens to the whole group happens to the individual. (p. 106)

This means that the community is foundational to human identity in traditional Africa. Everyone is socialised communally. As Mbiti (1990:106) further adds, mere physical birth is not enough to inculcate communal human identity; several 'rites of incorporation' are conducted to ensure the full communal integration of an individual.

\section{Ubuntu as human interdependence}

In ubuntu, the practical expression of solidarity is interdependence. Umuntu ngumuntu ngabantu highlights human interdependence. Many African proverbs that affirm hospitality, discourage and mock aloofness and stinginess. We are not just one but also dependent on each other. Tutu (1999:34-35) further projects ubuntu as concerned about the positive human characteristics such as generosity, hospitability, friendliness, caring and compassion. As Gichure (2015:127) highlights, many African philosophers believe that 'a significant element of Ubuntu culture is that it lends itself to a communal and traditional lifestyle in which every person is their neighbour's keeper'. Gathogo $(2007,2008)$ projects ubuntu as expressing and affirming hospitality. To Chisale (2018:1), ubuntu is 'synonymous with care ethics'. As Chisale adds, the 'interdependence of human beings on each other and other creation conceptualise Ubuntu as communal'. We have already seen this view expressed by Mbiti and Tutu. According to Gichure (2015:127), this means that 'the humanity of one is caught up, or inextricably bound up with, in that of others, that as humans people belong together in a bundle of life'. Consequently, hospitality is a foundational tenet of ubuntu, because it provides both space and means by which each individual can attain human identity. Similarly, stinginess and dependency syndrome are highly condemned. The Ndebele disdainfully mock a person who wants other people's things and yet stingily withholds his or her thingskokwabanye nwayinwayi, kokwakho finyofinyo. According to Gichure (2015):

Ubuntu wisdom and philosophy distinguishes between an individual existence of the self and the simultaneous existence of other persons, yet affirms that one only becomes fully human to the extent that he or she is included in relationships with others. (p. 127)

The emphasis is that one's life is not a privatised entity.

There is, therefore, a serious clash between the self-sufficient commodified and privatised self of the modern technological age and the communal self in traditional Africa that thrives on solidarity and interdependence with other people.

\section{The image of God in responding to the commodification of human identity in an ubuntu professing technological world}

Theologically, how can we evaluate the modern technological world's commodification of human identity and the resultant privatisation of self in the ubuntu professing African context as described above? Christians in modern Africa experiencing rapid technological growth live between the two competing commodification of human identity by technology and the communalising of human identity by ubuntu philosophy. This means that, in the modern technological world in Africa, the theology of human identity must respond to the commodification of human identity by technology and the communalisation of human identity in ubuntu philosophy.

\section{The image of God challenges the commodification of human identity}

The image of God is foundational in the Christian discourse on human identity because it is theologically foundational to the essence of human identity. A Christian theological reflection on human identity cannot be complete without considering the image of God. The main biblical texts on the image of God are Genesis 1:26-27; 5:1-3 and 9:1-7. Exegetical debates on these biblical texts and the various theories on the image of God are beyond the scope of this article. The article is only interested in highlighting that whatever the image is, it rejects the commodification of human beings by modern technology and the exclusive communalising of human identity in ubuntu philosophy that ends up destroying a person's independence.

The biblical view of people is founded on the declaration that 'God created humankind in his image, in the image of God he created them; male and female he created them' (Gn 1:27). However, it is important to realise, as pointed out by Peters (2010:218-219), that the book of Genesis does not show if the imago dei is a physical, metaphysical or moral quality that the human person or human race possesses. Yet, it is significant that both the male and the female are created in the image of God. Reflecting on the biblical declaration of the creation of all human beings in the image of God, Jones (2016:226) asserts that inherent in the doctrine of the image of God is resistance to the commodification of humanity. To Jones (2016:230): 'The radical inclusivity of the imago resists commodification, testifying that every human is fully human and ought not be bought or sold'. Therefore, in creating them male and female God gave each of them particular differences and in creating both of them in his own image, God gave male and female 'universal worth' (Jones 2016:230). In other words:

The nature of the imago as both universal and particular means that it contains built-in resistance to the commodification of human bodies. All Christians - universal and particularly - are called to witness to that resistance by rejoicing in the freedom of our bodies from the market and by rebelling wherever that liberty is denied. (p. 232) 
Therefore, the biblical declaration that human beings are created in God's image challenges all forms of commodifying human beings. This includes commodifying them by trafficking them to be bought and sold as slaves; commodifying them by treating them as things of pleasure, such as in advertisements; and commodifying them by basing the worth of their human identity on the commodities and technologies they possess such as in the materialistic modern technological age. Therefore, a consideration of the image of God calls for the upholding of dignified human identity. The image of God calls for human identity to be based on nothing else but God's affirmation of human beings as in his image and likeness. The image of God stands against the 'thingification' of humanity.

\section{Basing ubuntu on the image of God to challenge the commodification of human identity}

In an African context where ubuntu is foundational to the traditional African worldview of human identity, ubuntu must be informed by the image of God in order to effectively challenge the commodification of human identity in the modern technological age. As a tenet that promotes human solidarity and interdependence, ubuntu must be upheld because it provides a meaningful framework of pursuing the common good of the society. However, from a Christian theological perspective to meaningful challenge the notion of human self-sufficiency and independence nurtured by the modern technological age, ubuntu must be reformed by the image of God. Despite its many positive communal virtues, ubuntu is in many ways 'exclusive' by 'creat $[i n g]$ exclusionary identities which are often viewed as "others" within specific boundaries' (Manyonganise 2015:3). In agreement, Magezi (2017:114) finds that ubuntu defines community narrowly by referring to people 'bound geographically and relationally'. In other words, ubuntu provincially focused as it 'tends to exclude people who do not come from the same geographical area (ethnicity) or not filially related' (Magezi 2017:114).

The image of God is essentially relational and therefore challenges ubuntu to broaden its definition of community and be inclusive. As Horton (2011) points out:

To be created in God's image is to be called persons in communion. There was no moment when a human being was actually a solitary, autonomous, unrelated entity; self-consciousness always included consciousness of one's relation to God, to each other, to one's place in the wider created environment. (p. 387)

Horton's perspective of the relational nature of the image of God expresses the Trinitarian view of God as a relational being. Embracing Robert Jenson's observation, Horton (2011:388) highlights that God's creating 'Word' is not 'an unspoken mental form actualised by the will (as believed by Augustine); rather, it is an actual utterance'. Creation was through God's intentional active participation. The significance of this is that being human is the result of being mentioned by God, which implies that:
Even those who are not mentioned by us - the infirm in nursing homes and hospitals, the unborn, those who are deemed 'nothing' by society, even the dead - are nevertheless somebody because they have been mentioned by God. God has called them into existence, and he will have the last world at their final resurrection. Neither their ability to reason nor will, but God's covenantal speech, is the source of their personhood. (Horton 2011:388)

It is beyond the scope of this article to unpack Horton's covenantal perspective. However, Horton essentially emphasises the need to recognise and uphold the image of God in all people, even those held in miserable and humiliating social, physical and medical conditions that may relegate them to a state of non-people. Furthermore, as raised by Horton, our view of people, particularly those in undesirable circumstances and those who have identities that are unacceptable to us, must be eschatologically informed, because at the final resurrection, all dehumanising elements will be eradicated and all human beings will enter a perfect human state of being in the image of God. Therefore, the image of God challenges ubuntu to view other people with the neighbourly perspective of the Good Samaritan.

When ubuntu is informed and shaped by the image of God, it means that African churches will not be lonely places where people are ignored, devalued and dehumanised by other Christians to the point of being driven to find solace in social media, which ends up commodifying them.

\section{The image of God calls for the humanisation of technology}

The image of God calls for the humanisation of technology because commodification dehumanises people. However, technology must be embraced in a humanising manner that does not commodify human identity. Peters (2010:238) highlights that technologies such as scientific enhancers lack 'any vision of the Godlike life'. That is, while modern technology has greatly improved life and even enabled people to cope with, and even transcend, a host of human limitations, yet it lacks 'the Christian vision of a redeemed life characterised by love of God and love of neighbour' (Peters 2010:238). This calls for technology to be used in a way that upholds the fact of human beings being in the image of God. Pointing to biblical texts such as Leviticus 25:39-43; Amos 8:6 and Matthew 21:12-13, Jones (2016:232) points out: 'Scripture teaches that human beings are persons and not market goods, and it does so through direct and indirect critique of markets for human beings'. Use of technology must not dehumanise people by commodifying them. Jones (2016:233) adds that texts such as 1 Corinthians 6:20, Acts 20:28 and 1 Peter 1:18-19 that portray Christ's act of saving people in market metaphors, like bought with a price by Christ and obtained with the blood of Christ, bar the commodification of human beings. The image of God calls for the humanisation of technology by not reducing them to commodities but enabling their freedom to glorify God. 


\section{Towards de-commodification of human identity in the modern technological age in Africa}

What resources does the church have that it can employ to promote meaningful human identity in the modern technological age?

\section{A pastoral concern for human dignity}

An important resource for the church is its pastoral mandate by which it cares for people. We have noted Chisale's view that ubuntu is synonymous with the ethics of care. In the middle of the onslaught from technology against dignified human identity, the church must use its pastoral resource to protect human dignity from being commodified by technology. The church must be concerned about the mass migration to the virtual world and the overdependence on electronic bandwidth instead of interpersonal links in human relationships. The church must use its pastoral resource to attend to the social and emotional needs that keep people hooked on technological gadgets and address their commodification by technology.

\section{A communal resource of human affirming church relationships}

The communality of the church is an important resource of de-commodifying human identity in the technological age. The technological age promotes the search for alternative communities because traditional communities are losing their significant meaning on people. The Bible describes the church in communal and relational terms. The church is challenged to foster meaningful interpersonal relationships that can protect people from trends that lead to commodification by technology.

\section{A moral resource of promoting responsible use of technology}

The question can be asked, is it all doom and gloom when it comes to technology, or does it have a place in promoting a sense of humanity? The value and need of technology in modern life has already been affirmed in the above sections. Indeed, the extent to which technology has stretched its tentacles to all the departments of modern people's lives means that it (technology) is here to stay. Therefore, rather than resist it, Christians must embrace technology and promote its responsible use. There are already numerous smart technologies, online programmes and applications used for evangelism and discipleship. Many Christians already rely on several well-developed online applications for daily devotions. Renowned American pastors such as Charles F. Stanley of InTouch Ministries and Charles R. Swindoll of Insight for Living Ministries are a few notable examples of many Christian ministers who have positively embraced technology and use it effectively to evangelise and disciple believers. However, these smart applications should not function in ways that replace the believer's need for belonging to the corporeal body of Christ. There is need to guard that the development of online spiritual and devotional programmes do not produce privatised Christians who shun active membership in churches. These developments must enhance, instead of undermine, the corporeality of Christian fellowship.

Furthermore, technology has an undisputable place in promoting a sense of humanity and, therefore, theology must provide moral resources of using technology responsibly and not in ways that harm humanity. Technology can play a powerful role in theological education and training. Technology can also be used by social networks in promoting awareness of social justice issues and in mobilising communities and individuals to address social, economic and political issues.

However, the church must be concerned when many people are bankrupted by overspending on internet data and expensive smart gadgets. Many people are left in crippling debts as credit stores offer them deal after deal on the latest version of smartphones. Furthermore, addiction to smartphones results in wasted time and neglected relationships. This calls for the church to realise its moral resource through which it can promote safe use of technology.

\section{Conclusion}

This article attempted to respond to the question: From the perspective of the African communal tenet of ubuntu that places human identity within communal solidarity and interdependence, how can we theologically respond to the commodification of human identity in the modern technological age? In answering this question, the article first described how modern technological age promotes a form of human self-sufficiency that leads to the commodification of human identity. By commodification it was meant the tendency by technological companies to treat people as commodities to be traded on their networks. Commodification was also defined in terms of associating human identity with the possession of technological commodities, which results in materialism. The article further highlighted the link between commodification of human identity and privatisation of self, meaning that much of the high interconnectivity happens on the outside and not on the inside. This results in people being well connected online but unconnected in real life and the maintenance of a footprint on social media that hides our inner selves from the world. This commodification and privatisation of self was critiqued from the ubuntu philosophy expressed by the Nguni proverb umuntu ngumuntu ngabantu. It was argued that the image of God must be used to critique the commodification of human identity by technology. Finally, some steps that the churches can use to mitigate against the commodification of human identity were presented. As technology is becoming the foundation of our modern societies, rather than resist it, Christians must embrace it and form their use of it with the image of God to avoid being commodified by it. 


\section{Acknowledgements}

The author would like to thank the North-West University for its assistance and the peer reviewers for their constructive comments on the article.

\section{Competing interests}

The author declares that he has no financial or personal relationships that may have inappropriately influenced him in writing this article.

\section{References}

Bess, M., 2010, 'Enhanced humans versus "Normal People": Elusive definitions', Journal of Medicine and Philosophy 35(6), 641-655. https://doi.org/10.1093/ jmp/jhq053

Brulin, S., 2013, 'Being human in a technological age: A study of the impacts of smart technology usage', Department of Informatics, Master's thesis, Umea University.

Cambridge Dictionary, 2018, Commodification: Meaning, viewed 04 January 2018 from https://dictionary.cambridge.org/dictionary/english/commodification

Chisale, S.S., 2018, 'Ubuntu as care: Deconstructing the gendered Ubuntu', Verbum et Ecclesia 39(1), a1790. https://doi.org/10.4102/ve.v39i1.1790

Cole-Turner, R., 2018, 'Commodification and transfiguration: Socially mediated identity in technology and theology', Paper presented at the 23rd SASRF/ISSRSEMINAR 2018, University of South Africa, Pretoria, 6-7th September 2018.

Degrazia, D., 2005, 'Enhancement technologies and human identity', Journal of Medicine and Philosophy 30(3), 261-283. https://doi.org/10.1080/03605310 590960166

Gade, C.B.N., 2011, 'The historical development of the written discourses on ubuntu', South African Journal of Philosophy 30(3), 303-329. https://doi.org/10.4314/ sajpem.v30i3.69578

Gathogo, J.M., 2007, 'Revisiting African hospitality in post-colonial Africa', Missionalia $35(2), 108-130$.

Gathogo, J.M., 2008, 'African philosophy as expressed in the concepts of hospitality and ubuntu', Journal of Theology for Southern Africa 130, 39-53.

Gichure, C., 2015, 'Human nature/identity: The ubuntu world view and beyond' viewed 28 August 2018, from https://su-plus.strathmore.edu/bitstream/handle/ $11071 / 3758 /$ Human $\% 20$ nature.pdf?sequence $=1 \&$ is Allowed $=y$

Hadebe, N.M., 2017, 'Commodification, decolonisation and theological education in Africa: Renewed challenges for African theologians', HTS Teologiese Studies/ Theological Studies 73(3), a4550. https://doi.org/10.4102/hts.v73i3.4550
Horton, M., 2011, The Christian faith: A systematic theology for pilgrims on the way, Zondervan, Grand Rapids, MI.

Illing, S., 2018, 'Technology isn't just changing society, it's changing what it means to be human', viewed 19 June 2018, from https://www.vox.com/technology/2018/ 2/23/16992816/facebook-twitter-tech-artificial-intelligence-crispr

Jones, B.F., 2016, 'Witnessing in freedom: Resisting commodification of the image', in B.F. Jones \& B.F. Barbeau (eds.), The image of God in an image driven age: Explorations in theological anthropology, pp. 225-241, IVP, Downers Grove, IL.

Letseka, M., 2012, 'In defence of ubuntu', Studies in Philosophy and Education 31(1), 47-60, viewed 19 September 2018, from https://doi.org/10.1007/s11217-011 9267-2

Magezi, V., 2015, 'Technologically changing African context and usage of information communication and technology in churches: Towards discerning emerging identities in church practice (a case study of two Zimbabwean cities)', HTS Teologiese Studies/Theological Studies 71(2), Art. 2625, 1-8. https://doi.org/ 10.4102/hts.v71i2.2625

Magezi, V., 2017, 'Ubuntu in flames - Injustice and disillusionment in post-colonial Africa: A practical theology for new "liminal ubuntu" and personhood', in J. Dreyer, Y. Dreyer, E. Foley \& M. Nel (eds.), Practicing ubuntu: Practical theological perspectives on injustice, personhood and human dignity, pp. 111-122, LIT Verlag, Zurich.

Manyonganise, M., 2015, 'Oppressive and liberative: A Zimbabwean woman's reflections on ubuntu', Verbum et Ecclesia 36(2), Art. \#1438, 1-7. https://doi. reflections on ubuntu', Verbur
org/10.4102/ve.v36i2.1438

Mbiti, J.S., 1990, African religions \& philosophy, Heinemann Educational Botswana, Gaborone.

Merriam-Webster Dictionary, 2018, Definition of commodify, viewed 04 January 2018, from https://www.merriam-webster.com/dictionary/commodify

Metz, T., 2011, 'Ubuntu as a moral theory and human rights in South Africa', African Human Rights Law Journal 11(2), 532-559.

Nyathi, P., 2001, Traditional ceremonies of AmaNdebele, Mambo, Gweru.

Peters, T., 2010, 'Can we enhance the Imago Dei?', in N. Murphy \& C.H. Knight (eds.) Human identity at the intersection of science, technology and religion, pp. 215-238, Ashgate, Surrey.

Sellen, A., Rogers, Y., Harper, R. \& Rodden, T., 2009, 'Reflecting human values in the digital age', Communications of the ACM 52(3), 58-66. https://doi.org/10.1145/ 1467247.1467265

Shutte, A., 2001, Ubuntu: An ethic of a new South Africa, Cluster, Pietermaritzburg.

Speckman, M.T., 2007, A biblical vision for Africa's development? Cluster Publications, Pietermaritzburg.

Taylor, J., 2011, 'Technology: Is technology stealing our (self) identities?', viewed 05 September 2018, from https://www.psychologytoday.com/us/blog/the-powerprime/201107/technology-is-technology-stealing-our-self-identities

Tutu, D., 1999, No future without forgiveness, Rider, London.

Wagner, K., 2018, 'This is how Facebook uses your data for ad targeting', viewed 15 October 2018, from https://www.recode.net/2018/4/11/17177842/facebookadvertising-ads-explained-mark-zuckerberg 